\title{
Natural Killer (NK) Cell Education Differentially Influences HIV Antibody-Dependent NK Cell Activation and Antibody-Dependent Cellular Cytotoxicity
}

\section{OPEN ACCESS}

Edited by:

Persephone Borrow,

University of Oxford,

United Kingdom

Reviewed by:

Anthony Jaworowski,

Burnet Institute, Australia

Guido Ferrari,

Duke University, United States

*Correspondence:

Nicole F. Bernard

nicole.bernard@mcgill.ca

Specialty section: This article was submitted

to HIV and AIDS,

a section of the journal

Frontiers in Immunology

Received: 01 June 2017 Accepted: 10 August 2017

Published: 24 August 2017

Citation:

Bernard NF, Kiani Z,

Tremblay-McLean A, Kant SA,

Leeks CE and Dupuy FP (2017)

Natural Killer (NK) Cell Education

Differentially Influences HIV

Antibody-Dependent NK Cell

Activation and Antibody-Dependent

Cellular Cytotoxicity.

Front. Immunol. 8:1033.

doi: 10.3389/fimmu.2017.01033

\author{
Nicole F. Bernard ${ }^{1,2,3,4 *}$, Zahra Kiani ${ }^{1,2}$, Alexandra Tremblay-McLean ${ }^{1,2}$, Sanket A. Kant ${ }^{1,2}$, \\ Christopher E. Leeks ${ }^{1,2}$ and Franck P. Dupuy
}

${ }^{1}$ Research Institute of the McGill University Health Centre, Montreal, QC, Canada, ${ }^{2}$ Division of Experimental Medicine, McGill University, Montreal, QC, Canada, ${ }^{3}$ Chronic Viral Illness Service, McGill University Health Centre, Montreal, QC, Canada,

${ }^{4}$ Division of Clinical Immunology, McGill University Health Centre, Montreal, QC, Canada

Immunotherapy using broadly neutralizing antibodies (bNAbs) endowed with Fc-mediated effector functions has been shown to be critical for protecting or controlling viral replication in animal models. In human, the RV144 Thai trial was the first trial to demonstrate a significant protection against HIV infection following vaccination. Analysis of the correlates of immune protection in this trial identified an association between the presence of antibody-dependent cellular cytotoxicity (ADCC) mediated by immunoglobulin G (IgG) antibodies (Abs) to HIV envelope (Env) V1N2 loop structures and protection from infection, provided IgA Abs with competing specificity were not present. Systems serology analyses implicated a broader range of $A b$-dependent functions in protection from HIV infection, including but not limited to ADCC and Ab-dependent NK cell activation (ADNKA) for secretion of IFN- $\gamma$ and CCL4 and expression of the degranulation marker CD107a. The existence of such correlations in the absence of bNAbs in the RV144 trial suggest that NK cells could be instrumental in protecting against HIV infection by limiting viral spread through Fc-mediated functions such as ADCC and the production of antiviral cytokines/chemokines. Beside the engagement of FcyRIIla or CD16 by the Fc portion of anti-Env IgG1 and IgG3 Abs, natural killer (NK) cells are also able to directly kill infected cells and produce cytokines/chemokines in an Ab-independent manner. Responsiveness of NK cells depends on the integration of activating and inhibitory signals through NK receptors, which is determined by a process during their development known as education. NK cell education requires the engagement of inhibitory NK receptors by their human leukocyte antigen ligands to establish tolerance to self while allowing NK cells to respond to self cells altered by virus infection, transformation, stress, and to allogeneic cells. Here, we review recent findings regarding the impact of inter-individual differences in NK cell education on Ab-dependent functions such as ADCC and ADNKA, including what is known about the HIV Env epitope specificity of ADCC competent Abs and the conformation of HIV Env on target cells used for ADCC assays.

Keywords: natural killer cells, antibody-dependent cellular cytotoxicity, antibody-dependent natural killer cell activation, natural killer cell education, CD16, inhibitory natural killer cell receptors, non-neutralizing antibodies, broadly neutralizing antibodies 


\section{INTRODUCTION}

There is great interest in developing an effective vaccine against HIV infection. It is generally acknowledged that inducing broadly neutralizing antibodies (bNAbs) would be a desirable goal for prophylactic HIV vaccines. The most potent bNAbs have been shown to protect against virus infection or to suppress viral replication in humanized mouse models and in rhesus macaques (1-6). Clinical trials conducted in HIV-infected humans, using the bNAbs VRC01 and 3BNC117, reduced HIV viral load by up to $2.5 \operatorname{logs}(7,8)$ and delayed viral rebound after antiretroviral therapy (ART) interruption $(9,10)$. However, there are still significant challenges to inducing such antibodies (Abs) through vaccination. BNAbs are rarely elicited in natural HIV infection and many exhibit high levels of affinity maturation (11-15). Despite this, progress has been made producing bNAbs in animal models using sequential cycles of boosting with defined immunogens (16). It is interesting to note that bNAbs able to protect humanized mice or rhesus macaques against challenge with HIV or simian/human immunodeficiency virus (SHIV) require an Fc region able to interact with $\mathrm{Fc}$ receptors ( $\mathrm{FcRs}$ ) on innate immune cells (17-19). One of these FcRs, FcyRIIIa, also known as CD16, is found on natural killer (NK) cells, macrophages, and monocyte subsets (20-22).

The HIV vaccine tested in the RV144 Thai trial is the only vaccine to date that conferred modest (approximately 31\%) but significant protection against HIV infection (23). Protection was not associated with the presence of bNAbs or cytotoxic $\mathrm{T}$ cell responses (24). Rather, protection from HIV infection in trial participants was associated with the presence of anti-HIV envelope (Env) specific immunoglobulin $\mathrm{G}$ ( $\mathrm{IgG}$ ) non-neutralizing Abs (nNAbs) able to mediate Ab-dependent cellular cytotoxicity (ADCC) provided no potentially competitive IgA Abs were present (24-27). Follow-up analyses using systems serology approaches confirmed findings from correlation analyses and identified links between anti-Env V1/V2-specific IgG, IgG3, and IgG1, and Ab-dependent functions such as ADCC, Ab-dependent cellular phagocytosis, Ab-dependent complement deposition, and Ab-dependent NK cell activation (ADNKA) for secretion of IFN- $\gamma$ and CCL4, and expression of CD107a in recipients of the RV144 vaccine (28). This raised the possibility that anti-HIV Env-specific nNAbs able to mediate ADCC and ADNKA activity may play a protective role against HIV infection.

Natural killer cells can be activated through Ab-dependent pathways that involve CD16 engagement by the $\mathrm{Fc}$ region of IgG1 and IgG3 Abs (29-35). They can also be activated by $\mathrm{Ab}$-independent missing self recognition mechanisms based on how they were educated during development. Activating NK cells by either mechanism leads to secretion of chemokines and cytokines and to the release of cytotoxic granules that lyse target cells. ADNKA is the term used to describe the activation of NK cells for chemokine/cytokine secretion and degranulation by Ab-dependent stimuli. ADCC, on the other hand, denotes the lysis of target cells by NK cells in the presence of an Ab bridge. In the literature, these two activities have often been incorrectly referred to as ADCC. NK cells are important effector cells for these two Ab-dependent functions. Here, we will review recent findings on Ab-dependent functions mediated by NK cells and explore what is known regarding the influence of NK cell education on ADNKA and ADCC.

\section{NK CELL EDUCATION}

Tolerance to self and the state of activation of NK cells is determined by an ontogenic process termed education. NK cell education requires the interaction of inhibitory NK receptors (iNKRs) with their cognate human leukocyte antigen (HLA) ligands on neighboring cells $(36,37)$. The education of NK cells determines how these cells will respond to infected, transformed, stressed, and allogeneic cells in an Ab-independent fashion. Education is a complex process whereby functionality is tuned by the number of iNKRs engaged, the strength of interactions between iNKRs and their ligands, and whether activating NK cell receptors are also engaged (38-44). NK cells lacking iNKRs for self-HLA ligands remain uneducated and hyporesponsive (45). iNKRs involved in NK cell education include NKG2A and the killer immunoglobulin-like receptors (KIR)3DL1, KIR2DL1, KIR2DL2, and KIR2DL3 (see Table 1). NKG2A is a C-type lectin receptor that forms a heterodimer with $\operatorname{CD} 94(46,47)$. It interacts with non-classical major histocompatibility complex class I (MHC-I) HLA-E antigens presenting 9-mer peptides cleaved from the leader sequence of several MHC-I proteins $(48,49)$. Both NKG2A and HLA-E have limited sequence variability and their effects on NK cell education were initially reported to be similar from one person to another (50). The inhibitory KIRs (iKIRs) recognize subsets of HLA antigens together with peptides (51). KIR3DL1 interacts with a subset of HLA-A and -B antigens belonging to the HLA-Bw4 (Bw4) group (52-54). Bw4 antigens differ from the remaining HLA-Bw6 (Bw6) HLA-B variants at amino acids $77-83$ of the HLA heavy chain (55). Bw6 isoforms do not interact with KIR3DL1 receptors such that KIR3DL1 ${ }^{+}$ NK cells from individuals carrying no $B w 4$ alleles are not educated through this receptor. KIR2DL3 and KIR2DL2 are encoded at the same locus and interact with HLA-C group 1 (C1) variants that have an asparagine at position 80 of the HLA heavy chain (56-58). The remaining HLA-C variants, belonging to the C2 group, have a lysine at this position and are ligands for KIR2DL1 (56). The KIR2DL3 receptor can also bind certain C2 variants, though with a lower affinity than either KIR2DL1 or KIR2DL2 $(57,59,60)$. Therefore, KIR2DL3 ${ }^{+}$NK cells from individuals expressing a C1 ligand are educated, but remain uneducated or modestly educated through this receptor in individuals who are negative for $\mathrm{C} 1$ ligands. By contrast, $\mathrm{KIR} 2 \mathrm{DL1}{ }^{+} \mathrm{NK}$ cells require the expression of a C2 ligand for education.

Genome-wide association studies (GWAS) confirm that genes influencing HIV viral load set point map to the MHC-I region on chromosome $6(61,62)$. MHC-I antigens encoded in this region form complexes with peptides, which are recognized by the $\mathrm{T}$ cell receptors on $\mathrm{CD}^{+} \mathrm{T}$ cells (63). It is well established that $\mathrm{CD} 8^{+} \mathrm{T}$ cells play an important role in HIV viral control (64-66). However, NKG2A and iKIR on NK cells also recognize MHC-I peptide complexes $(48,49,52,53,56)$. Both epidemiological and functional studies have implicated iKIRs, particularly KIR3DL1, in combination with certain Bw4 variants in protection from HIV 
TABLE 1 | Inhibitory natural killer (NK) cell receptors involved in NK cell education.

\begin{tabular}{|c|c|c|c|c|c|}
\hline Receptor & Ligand & $\begin{array}{l}\text { aa at position } 80 \text { of the } \\
\text { human leukocyte antigen } \\
\text { (HLA) heavy chain }\end{array}$ & $\begin{array}{l}\text { Effect on education } \\
\text { when ligand is present }\end{array}$ & $\begin{array}{l}\text { Ligand levels in } \\
\text { HIV-infected cells }\end{array}$ & Reference \\
\hline NKG2A & $\begin{array}{l}\text { HLA-E + leader peptide from } \\
\text { HLA-A, -B, -C, and -G }\end{array}$ & & Enhanced & Maintained & $(48,49)$ \\
\hline $\begin{array}{l}\text { Killer immunoglobulin-like } \\
\text { receptors (KIR)3DL1 }\end{array}$ & $\begin{array}{l}\text { HLA-B*Bw4, HLA-A*23, } \\
{ }^{\star} 24 \text {, and }{ }^{\star} 32\end{array}$ & $\begin{array}{l}\text { Isoleucine }\left({ }^{\star} 80 \mathrm{l}\right) \text { or threonine } \\
\left({ }^{\star} 80 \mathrm{~T}\right)\end{array}$ & Enhanced & Downmodulated & $(52-54)$ \\
\hline KIR2DL1 & HLA-C2 & Lysine & Enhanced & $\begin{array}{l}\text { Maintained or downmodulated } \\
\text { depending on HIV isolate }\end{array}$ & $(56-60)$ \\
\hline KIR2DL2 & HLA-C1 (some HLA-C2) & Asparagine & Enhanced & $\begin{array}{l}\text { Maintained or downmodulated } \\
\text { depending on HIV isolate }\end{array}$ & $(56-60)$ \\
\hline KIR2DL3 & HLA-C1 (some HLA-C2) & Asparagine & Enhanced & $\begin{array}{l}\text { Maintained or downmodulated } \\
\text { depending on HIV isolate }\end{array}$ & $(56-60)$ \\
\hline
\end{tabular}

infection and slow disease progression in those already infected $(67,68)$. For example, individuals who are homozygous for KIR3DL $1^{\star} h{ }^{*} y$ genotypes and co-carry $H L A-B^{\star} 57\left({ }^{\star} h{ }^{*} y+B^{\star} 57\right)$ progress to AIDS more slowly and control HIV viral load better than $B w 6 \mathrm{hmz}$ (67). KIR3DL1 ${ }^{*} h{ }^{*} y$ genotypes encode receptors expressed at high levels (69) while HLA-B ${ }^{\star 57}$ is a Bw4 variant that is also expressed on the cell surface at a high density and is a potent ligand for KIR3DL1 (44). The effect of this KIR/ HLA combination on NK cell education is illustrated by the observation that KIR3DL1 ${ }^{+} \mathrm{NK}$ cells from ${ }^{*} h{ }^{*} y+B^{\star} 57$ carriers, compared to those from $B w 6 \mathrm{hmz}$, have a superior functional potential upon stimulation with HLA null cells and inhibit HIV replication more potently in autologous-infected $\mathrm{CD}^{+} \mathrm{T}$ cells through mechanisms that involve secretion of CC-chemokines $(41,70,71)$. An upstream region of HLA-C that plays a role in determining HLA-C expression levels was also associated with HIV control in individuals of European American origin in GWAS studies $(61,62)$. While the mechanism underlying this association is related to HLA-C expression levels and the potency of $\mathrm{CD}^{+} \mathrm{T}$ cell recognition of HLA-C-HIV peptide complexes, the potential involvement of NK cells has not been excluded (72).

A dimorphism at position -21 in the leader peptide of HLA-B antigens influences the delivery of peptides to either an NKG2A or iKIR focused NK cell response (73). The amino acid at this position corresponds to the HLA leader peptide's position 2, which is an anchor residue for HLA-E binding. A minority of HLA-B and all HLA-A and HLA-C antigens have a methionine at position $-21(-21 \mathrm{M})$ of the leader sequence. $-21 \mathrm{M}$ containing 9-mer peptides form stable complexes with HLA-E that are recognized by NKG2A. It is notable that the haplotypes carrying the $-21 \mathrm{M} H L A-B$ alleles rarely encode $\mathrm{Bw} 4$ or $\mathrm{C} 2$ isoforms that are KIR3DL1 and KIR2DL1 ligands, respectively (73). By contrast, 9-mer peptides that have a threonine at the $-21(-21 \mathrm{~T})$ residue present in most HLA-B antigens, form poor complexes with HLA-E. Consequently, this $-21 \mathrm{M} / \mathrm{T}$ dimorphism defines two types of HLA haplotypes. One haplotype group, encoding $-21 \mathrm{M}$ variants, is biased toward providing ligands for NKG2A and other group, encoding $-21 \mathrm{~T}$ variants, preferentially provides ligands for iKIR. This dimorphism appears to be clinically relevant in the context of HIV infection since the presence of $-21 \mathrm{M}$ HLA-B antigens is associated with higher susceptibility to HIV infection in HIV-discordant couples and with poorer NK cellmediated killing of $\mathrm{HIV}^{+}$cells than are $-21 \mathrm{~T}$ HLA-B antigens $(74,75)$. Together, these findings prompt a reconsideration of epidemiological and NK cell functional studies in the light of the contribution of NKG2A versus iKIR responses to the activation of NK cell populations expressing defined patterns of iNKR.

\section{THE INFLUENCE OF NK CELL EDUCATION IN ADNKA}

Antibody-dependent NK cell activation measures NK cell activation following incubation with $\mathrm{Ab}$ opsonized targets cells. Even though ADNKA depends on the presence of Ab, NK cell education can also influence NK cell activation through ADNKA. Many of the earlier reports describing a role for NK cell education in ADNKA used the CEM.NKr.CCR5 (CEM) cell line coated with recombinant HIV Env gp120 as target cells (76). CEM cells express the CCR5 co-receptor for HIV entry and are resistant to direct NK cell killing (77-79). CEM cells are negative for Bw4 and C2 antigens but express C1 antigens (80).

A higher frequency of KIR3DL1 ${ }^{+}$, than KIR3DL1- NK cells, from carriers of $K I R 3 D L 1 / B w 4$ genetic combinations secrete IFN$\gamma$ and express CD107a in responses to anti-HIV Ab opsonized gp120-coated CEM. This differential activation of KIR3DL1 ${ }^{+}$and KIR3DL1- NK cell populations also occurs when the stimulus is HIV-infected or gp120-coated allogeneic primary CD4 ${ }^{+} \mathrm{T}$ cells (76). As well, a higher frequency of KIR2DL1 ${ }^{+}$than KIR2DL1NK cells from carriers of educating KIR2DL1/HLA-C2 combinations secrete IFN- $\gamma$ in response to $\mathrm{HIV}$-infected autologous targets and gp120-coated CEM cells in the presence of anti-HIV Env-specific Abs in plasma from $\mathrm{HIV}^{+}$individuals (81). By contrast, if NK cells are from carriers of the non-educating KIR/ $H L A$ pair KIR2DL1/C1 hmz, KIR2DL1 ${ }^{+}$and KIR2DL1 ${ }^{-}$NK cells respond to anti-HIV Ab-dependent stimulation equivalently (81). These observations implicate NK cell education in NK cell responses to anti-HIV Ab opsonized gp120-coated CEM cells, infected allogeneic CEM cells, and gp120-coated primary CD4 ${ }^{+}$ T cells. CD16 engagement is also important in ADNKA activity as NK cell activation is always higher in the presence versus absence anti-HIV-specific Abs. 
Gooneratne et al. have speculated that ADCC activity directed at allogeneic $\mathrm{HIV}$-infected cells may play a role in protecting against infection with allogeneic HIV-infected cells. Secretion of CCL4 from activated NK cells can bind the CCR5 HIV co-receptor and block HIV entry into new target cells (82). Activated NK cells also secrete cytotoxic granules that can lyse HIV-infected target cells (83). It is plausible that ADCC activity directed at allogeneic HIV-infected cells contributed to the modest protection conferred by the RV144 HIV vaccine trial, in which ADCC competent antiEnv-specific Abs were generated and to the protection conferred to infants who remain uninfected despite exposure to breast milk from HIV-infected mothers $(24,84)$.

There is a lack of consensus regarding whether educated NK cell populations respond more robustly than their uneducated counterparts to stimulation with anti-HIV opsonized autologous gp120-coated cells. KIR3DL1 ${ }^{+}$and KIR2DL1 ${ }^{+} \mathrm{NK}$ cells from carriers of $K I R / H L A$ combinations able to support education through these receptors have been reported to respond better that their uneducated counterparts to HIV Ab-dependent activation $(81,85)$. These findings are consistent with results reported by Lang et al. (86). These observations have been interpreted as evidence that Ab-dependent activation of NK cells can overcome inhibitory signals mediated by the interaction of HLA ligand binding to self iKIR. However, this is not a general finding in that others have noted that ligands on autologous target cells to iNKR on educated NK cells suppress the activity of educated NK cells compared to that of their uneducated counterparts $(87,88)$. Further research is needed to understand what accounts for these discrepant results.

The experiments describing ADNKA in this section have used an inclusive gating strategy to compare how NK cell populations expressing, or not, one iNKR respond to anti-HIV opsonized target cells. When NK cells are stained inclusively for the presence of a single iNKR, the targeted population includes NK cells expressing other iNKRs not stained for. These other iNKRs could influence NK cell responses to HIV Ab opsonized target cells depending on which iNKR/HLA receptor ligand pairs contributed to the education of the NK cells studied. By using an Ab panel detecting KIR3DL1, KIR2DL1, KIR2DL3, and NKG2A on $\mathrm{CD}^{-}{ }^{-} \mathrm{CD} 56^{\mathrm{dim}} \mathrm{NK}$ cells, it will be possible to focus on NK cell populations expressing one of these iNKR to the exclusion of the others. Such Ab panels that also detect multiple NK cell functions using Abs conjugated with different fluorochrome have been designed $(89,90)$. In future studies, these Ab panels should be used to exclusively gate on NK cell populations expressing single iNKRs that detect functions induced by anti-HIV Ab opsonized target cells. Such an experimental approach will allow for a more precise definition of NK cell responses within population expressing single educating receptors to activation through missing self recognition of the ligands for these iKIR on allogeneic CEM cells in addition to signals received via ligation of CD16 (91).

The frequency of NK cells responding to stimulation in ADNKA assays displays inter-individual variation. One possible mechanism underlying the range of NK cell effector responses in ADNKA assays is likely related to inter-individual differences in iNKR/HLA ligand effects on NK cell education. KIR3DL1 allotypes differ in their cell surface expression levels, with high, low, and null expression allotype groups $(69,92-95)$. These KIR3DL1 allotypes also differ in their affinity for particular HLA-B allotypes $(44,96)$. KIR2D receptors differ in their affinity for $\mathrm{C} 1$ and $\mathrm{C} 2$ antigens $(57,60)$. HLA-A, -B, and -C antigens also differ in their cell surface expression levels (44, $72,97)$. Thus, these factors, the number of iNKR/HLA pairs participating in NK cell education in each study subject, and the presence of ligands on CEM cells that provide, or that fail to provide, inhibitory signals to NK cells may all influence NK cell activation levels in ADNKA assays. Several authors have tested expression levels for HLA-B and C allotypes and have examined the avidity of interactions of high and low expression KIR3DL1 receptor groups for HLA-B antigens with either an isoleucine or a threonine at position 80 of the HLA heavy chain $(44,69,72,98$, 99). The putative influence of inter-personal immunogenetics on ADNKA activity could be explored by correlating ADNKA activation levels with KIR3DL1/HLA-B, KIR2DL1/HLA-C2, and KIR2DL3/HLA-C1 affinity and expression levels as has been described by Boudreau et al. (44). For ADNKA, activation through education-dependent missing self-recognition and CD16 signaling influence NK cell activation while for ADCC the effect of education-dependent missing self-recognition is minimized due to the low frequency of single positive (SP) iKIR+ NK cells positive for CD16. The comparison of assay results where one or more of these receptor ligand interactions is blocked may provide further insights into the role of signaling through iNKR or CD16 in ADNKA and ADCC.

\section{MEASURING ADCC ACTIVITY}

As opposed to ADNKA, ADCC measures target cell phenomena arising from the bridging of effector and target cells by an $\mathrm{Ab}$ whose Fc portion binds CD16 on effector cells and whose Fab portion recognizes an antigen on target cells. In the context of ADCC function-directed HIV Env gp120-coated target cells, the target antigens recognized by ADCC competent Abs are HIV Env $(30,78,100)$. ADCC activity directed to HIV infected may also recognize Tat (100).

Early versions of anti-HIV ADCC assays measured ${ }^{51}$ Chromium release from target cells (101-103). These have been replaced by flow cytometry-based assays using either CEM cells coated with gp120 or gp140, HIV-infected CEM or HIV-infected primary $\mathrm{CD}^{+} \mathrm{T}$ cells as target cells. Primary HIV-infected target cells have included reactivated $\mathrm{CD}^{+} \mathrm{T}$ cells from $\mathrm{HIV}$-infected subjects or $\mathrm{CD}^{+}{ }^{+} \mathrm{T}$ cells infected with transmitted/founder $(\mathrm{T} / \mathrm{F})$ HIV isolates (104-106). The GranToxiLux ADCC (GTL-ADCC) assay measures the delivery of granzyme $B(\mathrm{GzB})$ to target cells, an early step in the pathway leading to target cell lysis (83, $107,108)$. In the GTL-ADCC assay, target cells are labeled with fluorescent and viability dyes before incubation with effector cells, either peripheral blood mononuclear cells (PBMCs) or NK cells in the presence of HIV-specific ADCC competent Abs and a GzB substrate. If ADCC is induced following incubation with HIV-specific Abs, effector cells will release GzB that will enter target cells and hydrolyze the GzB substrate, activating its fluorescence, which can be detected by flow cytometry. Thus, the GTL-ADCC assay provides an estimate of ADCC activity 
by measuring the number of viable targets that are positive for proteolytically active GzB.

Read outs for ADCC assays include the loss of target cells loaded with a fluorescent marker, infected with green fluorescent protein-tagged HIV, luciferase tagged HIV, or Gag p $24^{+}$cells (105, $106,108-113)$. The lactate dehydrogenase (LDH) release ADCC assay measures the loss LDH from dying target cells by ELISA $(76,114)$. The widely used rapid and fluorometric ADCC has been shown to not measure ADCC but rather the uptake of the membrane dye PKH-26 used to label target cells by monocytemediated trogocytosis $(115,116)$.

\section{THE SPECIFICITY OF ANTI-HIV ADCC COMPETENT AbS}

Both bNAbs and nNAbs can mediate ADCC activity provided they can stably bind to target cells $(105,106,113,117-121)$. HIV Env epitopes targeted by nNAbs include the immunodominant region of gp41 (122) and CD4-induced (CD4i) epitopes exposed by CD4 ligation of HIV Env on infected cells $(111,123,124)$. Examples of prototypic anti-Env-specific Abs specific for a CD4i epitope is $\mathrm{A} 32$, which belongs to the anti-cluster $\mathrm{A}$ Ab group targeting the $\mathrm{C} 1 / \mathrm{C} 2$ region and $17 \mathrm{~b}$, which recognizes the coreceptor binding site (CoRBS) $(119,125)$. Other nNAbs have been reported to recognize the CD4bs and the V3 loop of gp120, which are also targeted by bNAbs, though the nNAbs bind these epitopes in a manner that does not prevent HIV entry (126-130). At least some of the epitopes targeted by ADCC competent nNAbs are poorly exposed on CD4 unliganded cell surface Env trimers. This is mainly due to accessory proteins Nef and Vpu that downregulate cell surface CD4 making CD4i epitopes unavailable for $\mathrm{Ab}$ recognition $(111,120,131,132)$. Bruel et al. found that CEM cells infected with two laboratory-adapted HIV strains bound Abs from several classes of bNAb and nNAbs epitope specificity. If binding occurred, these Abs usually also mediated ADCC activity against these infected cells (106). However, when reactivated, HIV-infected cells from the reservoir of ART-treated $\mathrm{HIV}^{+}$individuals or $\mathrm{CD}^{+} \mathrm{T}$ cells infected with $\mathrm{T} / \mathrm{F}$ strains were used as target cells, several monoclonal nNAbs bound a lower frequency of infected cells with a lower affinity than did bNAbs. Furthermore, nNAbs, compared to bNAbs, exhibited poor ADCC activity against targets infected with such primary HIV strains $(105,106,113,117,133)$. This phenomenon is likely related to the inability of nNAbs to access epitopes in the closed unliganded conformation of HIV Env (134).

Non-neutralizing Abs, particularly those specific for CD4i epitopes, preferentially bind HIV-uninfected bystander cells present in cultures with $\mathrm{HIV}^{+} \mathrm{CD}^{+} \mathrm{T}$ cells $(106,135,136)$. HIVinfected $\mathrm{CD}^{+} \mathrm{T}$ cells can shed HIV Env gp120 leaving behind gp41 stumps (136). The shed gp120 binds CD4 on the surface of uninfected bystander $\mathrm{CD} 4^{+} \mathrm{T}$ cells. This interaction has the potential to open the closed Env conformation exposing CD4i epitopes, making bystander enhanced targets for CD4i-specific ADCC competent Abs.

Strategies to improve the targeting of the open Env conformation by ADCC competent nNAbs has prompted exploring the use of CD4 mimetics to increase the susceptibility of HIV-infected cells to $\operatorname{ADCC}(106,135,137,138)$. Richard et al. worked with CD4 mimetics that were unable to enhance the recognition of HIV-infected cells to A32 Abs by themselves (138). However, these small molecules initiated the opening of Env trimers enough to permit the binding of Abs such as $17 \mathrm{~b}$ with specificity for a conserved epitope overlapping the CoRBS. Once 17b bound, the trimeric Env structure opened sufficiently to allow binding of A32 and susceptibility to ADCC activity (138).

It should be noted that most studies measuring anti-HIV ADCC activity have used gp120- or gp140-coated CEM cells as targets. While such targets are easy to prepare and convenient to use, the HIV Env on coated cells is monomeric and differs quantitatively and conformationally from trimeric Env found on the surface of HIV-infected cells. On coated cells, CD4 remains on the target cell surface while it is downregulated on infected cells unless Nef and/or Vpu HIV deletion mutants are used for infection. This needs to be kept in mind when interpreting the results of studies using coated cells as targets.

\section{THE INFLUENCE OF NK CELL EDUCATION ON ADCC ACTIVITY}

The GTL-ADCC assay using gp120-coated CEM cells as targets was used to show that education of effector populations through KIR3DL1 had no significant effect on the percent of $\mathrm{GzB}^{+}$ $\left(\% \mathrm{GzB}^{+}\right)$target cells generated in a GTL-ADCC assay (139). There may be several explanations for this observation. One possibility is that NK cells are not the main effector cell in the GTL-ADCC assay. A drawback of using PBMCs as effector cells in ADCC assays is that it is difficult to draw conclusions regarding which effector population is responsible for GzB delivery to the target cells. Several Fc $\gamma$ receptor-expressing cell types, including NK cells, monocytes/macrophages, and $\gamma \delta$ T cells, are capable of mediating ADCC $(107,115,140-144)$. To confirm that NK cells are the source of ADCC activity in the GTL-ADCC assay, Pollara et al. used effector PBMCs depleted of $\mathrm{CD} 56^{+} \mathrm{CD} 16^{+} \mathrm{NK}$ cells and observed that ADCC responses declined by over $66 \%(145,146)$. Purified NK cells and PBMCs from the same donors produced similar $\% \mathrm{GzB}^{+}$target cells (107). Together, these findings indicate that the GTL-ADCC assay is measuring NK cell-mediated ADCC responses.

In the GTL-ADCC assay, PBMC effector cells are a heterogeneous population that includes NK cells educated through 1, 2, or more iKIR and/or NKG2A. An Ab panel detecting KIR3DL1, KIR2DL1, KIR2DL3, and NKG2A on CD3 ${ }^{-}$CD $56^{\text {dim }}$ NK cells was used to gate exclusively on $\mathrm{SPiNKR}^{+} \mathrm{NK}$ cells. NK cells SP for iKIR had significantly lower frequencies of $\mathrm{CD} 16^{+}$cells than $\mathrm{did}$ SPNKG $2 \mathrm{~A}^{+}$or $\mathrm{NKG}_{2} \mathrm{~A}^{-} \mathrm{iKIR}^{-} \mathrm{NK}$ cells (147). $\mathrm{iKIR}^{+} \mathrm{NK}$ cells are educated if they develop in a setting in which the iKIR's ligand is co-expressed. The implication of this observation is that educated $\mathrm{SPiKIR}^{+} \mathrm{NK}$ cells would be poor ADCC effector cells as a median of $<5 \%$ of them are $\mathrm{CD} 16^{+}$(Figure 1 ). This could account for the lack of an effect of KIR3DL1-mediated NK cell education on the $\% \mathrm{GzB}^{+}$target cells generated in the GTL-ADCC assay $(139,147)$. Thus, it would be expected that $\mathrm{NKG}_{2} \mathrm{~A}^{+} \mathrm{NK}$ cells are superior 

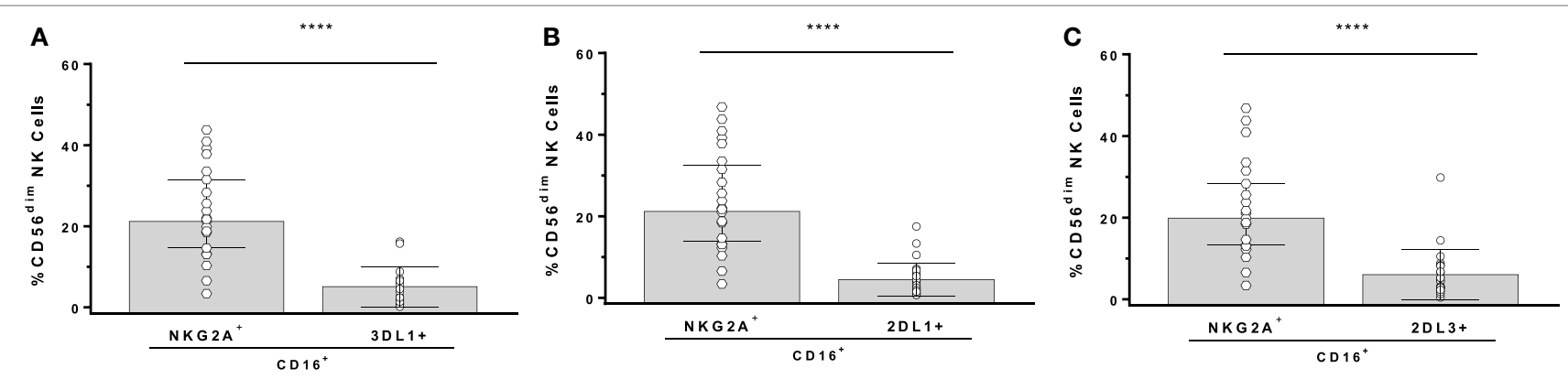

FIGURE 1 | Comparison of the frequency of CD16 ${ }^{+}$cells among CD3-CD56 dim natural killer (NK) cells stained for antibodies with NKG2A, KIR3DL1 (3DL1+), KIR2DL1 $\left(2 \mathrm{DL} 1^{+}\right)$, and KIR2DL3 (2DL3+). Comparison of single-positive (SP)NKG2A with SP3DL1 (A), SPNKG2A with SP2DL1 (B), and SPNKG2A with SP2DL3 (C). Each point represents a single individual, bar height, and error bars represent median and interquartile range for the data set. Wilcoxon matched pairs tests were used to determine the significance of between group differences $\left({ }^{\star \star \star \star} p<0.0001\right)$

to $\mathrm{iKIR}^{+} \mathrm{NKG} 2 \mathrm{~A}^{-} \mathrm{NK}$ cells as effector cells in the GTL-ADCC

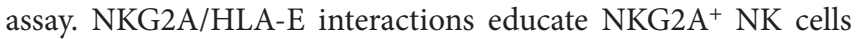
and these receptor ligand pairs are widely expressed with limited inter-individual variation. Their influence on NK cell education would have limited between-subject variation. If ADCC activity is an important correlate of protection against HIV, these findings suggest that inter-individual variation in NK effector cell education based on which iKIR/HLA receptor/ligand pairs are present would have a minimal impact on ADCC potency at the level of HIV-infected target cell lysis or suppression of replication. Together, these findings illustrate that the potency of NK cell education and functional activation of NK effector cells does not predict the $\% \mathrm{GzB}^{+}$generated by $\mathrm{ADCC}$.

In summary, factors important in determining ADNKA and ADCC activity differ from each other. The role of NK cell education in ADCC activity is limited by the low frequency of $\mathrm{CD}_{16}{ }^{+} \mathrm{NK}$ cells among $\mathrm{SPiKIR}^{+} \mathrm{NK}$ cells that have the potential to be educated through iKIR/HLA ligand interactions. Thus, a higher frequency of either uneducated NK cells or NK cells educated through NKG2A than those educated through iKIR are $\mathrm{CD} 16^{+}$and able to mediate ADCC. On the other hand, both CD16 engagement and missing self-recognition contribute to ADNKA. The consequences of these findings for HIV vaccines is that NK cell education should contribute minimally to interindividual differences in target cell lysis by ADCC. Furthermore, NK cell activation by Ab-dependent HIV-infected cell stimuli will vary depending on how NK cells are educated, the nature of the stimulatory cell and effect of HIV infection on cell surface MHC-I expression $(90,148)$.

\section{CONCLUDING REMARKS}

Arguing for a role for anti-HIV ADNKA and/or ADCC activity in protection from infection are the findings from the RV144 vaccine trial, which identified ADCC activity as a correlate of protection that was frequently linked to ADNKA activity $(24,27,28)$. Moreover, antigenic drift from ADCC targeting Env epitopes has been documented, highlighting a role for ADCC being able to exert anti-HIV immune pressure (149). Of note, it is unlikely that bNAbs contributed to either of these findings as neither RV144 vaccinated individuals (24) nor most $\mathrm{HIV}^{+}$persons make HIV-specific bNAbs. Suppression of HIV viral load in $\mathrm{HIV}$-infected persons receiving the bNAb 3BNC117 is likely not solely due to virus neutralization as this treatment also appears to clear infected cells (133). Also, the beneficial effect of treatment with several bNAbs depends on IgG Fc region effects (17-19). On the other hand, several attempts to show that nNAbs can protect against infection in rhesus macaques infected with SHIV have failed, though passive transfer of these Abs may have suppressed viremia or restricted the number of $\mathrm{T} / \mathrm{F}$ viruses in some cases (122, 150-152). By contrast, the passive transfer of the most active bNAbs mediates sterilizing protection in primate models (1-6). The protective role of anti-HIV nNAbs and/or how to manipulate the ability of these Abs to protect from HIV infection or how to use them therapeutically is an active area of research with several questions left to answer.

\section{AUTHOR CONTRIBUTIONS}

Substantial contributions to the conception or design of the work (NB, ZK, AT-M, CL, SK, and FD). Drafting the work or revising it critically for important intellectual content $(\mathrm{NB}, \mathrm{ZK}$, AT-M, CL, SK, and FD). Final approval of the version to be published (NB, ZK, AT-M, CL, SK, and FD). Agreement to be accountable for all aspects of the work in ensuring that questions related to the accuracy or integrity of any part of the work are appropriately investigated and resolved (NB, ZK, AT-M, CL, SK, and FD).

\section{FUNDING}

This work was supported by the Canadian Institutes for Health Research (MOP-142494 and THA-118628), and the Fonds de Recherche du Québec-Santé (FRQ-S) AIDS and Infectious Diseases Network. AT-M was supported by a Canadian Association for HIV Research Abbvie Master's Award in Basic Science. SK was supported by an M.Sc. scholarship from the Research Institute of the McGill University Health Centre (RI-MUHC). NB is a member of the RI-MUHC, an institution funded in part by the FRQ-S. 


\section{REFERENCES}

1. Klein F, Halper-Stromberg A, Horwitz JA, Gruell H, Scheid JF, Bournazos S, et al. HIV therapy by a combination of broadly neutralizing antibodies in humanized mice. Nature (2012) 492(7427):118-22. doi:10.1038/ nature 11604

2. Horwitz JA, Halper-Stromberg A, Mouquet H, Gitlin AD, Tretiakova A, Eisenreich TR, et al. HIV-1 suppression and durable control by combining single broadly neutralizing antibodies and antiretroviral drugs in humanized mice. Proc Natl Acad Sci U S A (2013) 110(41):16538-43. doi:10.1073/ pnas. 1315295110

3. Barouch DH, Whitney JB, Moldt B, Klein F, Oliveira TY, Liu J, et al. Therapeutic efficacy of potent neutralizing HIV-1-specific monoclonal antibodies in SHIV-infected rhesus monkeys. Nature (2013) 503(7475):224-8. doi:10.1038/ nature 12744

4. Shingai M, Nishimura Y, Klein F, Mouquet H, Donau OK, Plishka R, et al. Antibody-mediated immunotherapy of macaques chronically infected with SHIV suppresses viraemia. Nature (2013) 503(7475):277-80. doi:10.1038/ nature 12746

5. Gautam R, Nishimura Y, Pegu A, Nason MC, Klein F, Gazumyan A, et al. A single injection of anti-HIV-1 antibodies protects against repeated SHIV challenges. Nature (2016) 533(7601):105-9. doi:10.1038/nature17677

6. Moldt B, Rakasz EG, Schultz N, Chan-Hui PY, Swiderek K, Weisgrau KL, et al. Highly potent HIV-specific antibody neutralization in vitro translates into effective protection against mucosal SHIV challenge in vivo. Proc Natl Acad Sci U S A (2012) 109(46):18921-5. doi:10.1073/pnas.1214785109

7. Caskey M, Klein F, Lorenzi JC, Seaman MS, West AP Jr, Buckley N, et al. Viraemia suppressed in HIV-1-infected humans by broadly neutralizing antibody 3BNC117. Nature (2015) 522(7557):487-91. doi:10.1038/ nature14411

8. Lynch RM, Boritz E, Coates EE, DeZure A, Madden P, Costner P, et al. Virologic effects of broadly neutralizing antibody VRC01 administration during chronic HIV-1 infection. Sci Transl Med (2015) 7(319):319ra206. doi:10.1126/scitranslmed.aad5752

9. Scheid JF, Horwitz JA, Bar-On Y, Kreider EF, Lu CL, Lorenzi JC, et al. HIV-1 antibody 3BNC117 suppresses viral rebound in humans during treatment interruption. Nature (2016) 535(7613):556-60. doi:10.1038/ nature 18929

10. Bar KJ, Sneller MC, Harrison LJ, Justement JS, Overton ET, Petrone ME, et al. Effect of HIV antibody VRC01 on viral rebound after treatment interruption. N Engl J Med (2016) 375(21):2037-50. doi:10.1056/NEJMoa1608243

11. Burton DR, Hangartner L. Broadly neutralizing antibodies to HIV and their role in vaccine design. Annu Rev Immunol (2016) 34:635-59. doi:10.1146/ annurev-immunol-041015-055515

12. West AP Jr, Scharf L, Scheid JF, Klein F, Bjorkman PJ, Nussenzweig MC. Structural insights on the role of antibodies in HIV-1 vaccine and therapy. Cell (2014) 156(4):633-48. doi:10.1016/j.cell.2014.01.052

13. Rusert P, Kouyos RD, Kadelka C, Ebner H, Schanz M, Huber M, et al. Determinants of HIV-1 broadly neutralizing antibody induction. Nat Med (2016) 22(11):1260-7. doi:10.1038/nm.4187

14. Mouquet H. Antibody B cell responses in HIV-1 infection. Trends Immunol (2014) 35(11):549-61. doi:10.1016/j.it.2014.08.007

15. Klein F, Diskin R, Scheid JF, Gaebler C, Mouquet H, Georgiev IS, et al. Somatic mutations of the immunoglobulin framework are generally required for broad and potent HIV-1 neutralization. Cell (2013) 153(1):126-38. doi:10.1016/j. cell.2013.03.018

16. Briney B, Sok D, Jardine JG, Kulp DW, Skog P, Menis S, et al. Tailored immunogens direct affinity maturation toward HIV neutralizing antibodies. Cell (2016) 166(6):1459-70.e11. doi:10.1016/j.cell.2016.08.005

17. Hessell AJ, Hangartner L, Hunter M, Havenith CE, Beurskens FJ, Bakker JM, et al. Fc receptor but not complement binding is important in antibody protection against HIV. Nature (2007) 449(7158):101-4. doi:10.1038/ nature 06106

18. Bournazos S, Klein F, Pietzsch J, Seaman MS, Nussenzweig MC, Ravetch JV. Broadly neutralizing anti-HIV-1 antibodies require Fc effector functions for in vivo activity. Cell (2014) 158(6):1243-53. doi:10.1016/j.cell.2014.08.023

19. Halper-Stromberg A, Lu CL, Klein F, Horwitz JA, Bournazos S, Nogueira L, et al. Broadly neutralizing antibodies and viral inducers decrease rebound from HIV-1 latent reservoirs in humanized mice. Cell (2014) 158(5):989-99. doi:10.1016/j.cell.2014.07.043

20. Nimmerjahn F, Ravetch JV. Fcgamma receptors as regulators of immune responses. Nat Rev Immunol (2008) 8(1):34-47. doi:10.1038/nri2206

21. Trinchieri G, Valiante N. Receptors for the Fc fragment of IgG on natural killer cells. Nat Immun (1993) 12(4-5):218-34.

22. Bournazos S, Ravetch JV. Fcgamma receptor pathways during active and passive immunization. Immunol Rev (2015) 268(1):88-103. doi:10.1111/ imr.12343

23. Rerks-Ngarm S, Pitisuttithum P, Nitayaphan S, Kaewkungwal J, Chiu J, Paris R, et al. Vaccination with ALVAC and AIDSVAX to prevent HIV-1 infection in Thailand. N Engl J Med (2009) 361(23):2209-20. doi:10.1056/NEJMoa 0908492

24. Haynes BF, Gilbert PB, McElrath MJ, Zolla-Pazner S, Tomaras GD, Alam SM, et al. Immune-correlates analysis of an HIV-1 vaccine efficacy trial. $N$ Engl $J$ Med (2012) 366(14):1275-86. doi:10.1056/NEJMoal113425

25. Yates NL, Liao HX, Fong Y, DeCamp A, Vandergrift NA, Williams WT, et al. Vaccine-induced Env V1-V2 IgG3 correlates with lower HIV-1 infection risk and declines soon after vaccination. Sci Transl Med (2014) 6(228):228ra39. doi:10.1126/scitranslmed.3007730

26. Tomaras GD, Ferrari G, Shen X, Alam SM, Liao HX, Pollara J, et al. Vaccineinduced plasma IgA specific for the $\mathrm{C} 1$ region of the HIV-1 envelope blocks binding and effector function of IgG. Proc Natl Acad Sci U S A (2013) 110:9019-24. doi:10.1073/pnas.1301456110

27. Chung AW, Ghebremichael M, Robinson H, Brown E, Choi I, Lane S, et al. Polyfunctional Fc-effector profiles mediated by IgG subclass selection distinguish RV144 and VAX003 vaccines. Sci Transl Med (2014) 6(228):228ra38. doi:10.1126/scitranslmed.3007736

28. Chung AW, Kumar MP, Arnold KB, Yu WH, Schoen MK, Dunphy LJ, et al. Dissecting polyclonal vaccine-induced humoral immunity against HIV using systems serology. Cell (2015) 163(4):988-98. doi:10.1016/j.cell.2015. 10.027

29. Brier AM, Chess L, Schlossman SF. Human antibody-dependent cellular cytotoxicity. Isolation and identification of a subpopulation of peripheral blood lymphocytes which kill antibody-coated autologous target cells. J Clin Invest (1975) 56(6):1580-6. doi:10.1172/JCI108240

30. Koup RA, Sullivan JL, Levine PH, Brewster F, Mahr A, Mazzara G, et al. Antigenic specificity of antibody-dependent cell-mediated cytotoxicity directed against human immunodeficiency virus in antibody-positive sera. $J$ Virol (1989) 63(2):584-90.

31. Bruggemann M, Williams GT, Bindon CI, Clark MR, Walker MR, Jefferis R, et al. Comparison of the effector functions of human immunoglobulins using a matched set of chimeric antibodies. JExp Med (1987) 166(5):1351-61. doi:10.1084/jem.166.5.1351

32. Warncke M, Calzascia T, Coulot M, Balke N, Touil R, Kolbinger F, et al. Different adaptations of IgG effector function in human and nonhuman primates and implications for therapeutic antibody treatment. J Immunol (2012) 188(9):4405-11. doi:10.4049/jimmunol.1200090

33. Boesch AW, Brown EP, Cheng HD, Ofori MO, Normandin E, Nigrovic PA, et al. Highly parallel characterization of IgG Fc binding interactions. MAbs (2014) 6(4):915-27. doi:10.4161/mabs.28808

34. Fauriat C, Long EO, Ljunggren HG, Bryceson YT. Regulation of human NK-cell cytokine and chemokine production by target cell recognition. Blood (2010) 115(11):2167-76. doi:10.1182/blood-2009-08-238469

35. Bruhns P, Iannascoli B, England P, Mancardi DA, Fernandez N, Jorieux S, et al. Specificity and affinity of human Fcgamma receptors and their polymorphic variants for human IgG subclasses. Blood (2009) 113(16):3716-25. doi:10.1182/blood-2008-09-179754

36. Kim S, Poursine-Laurent J, Truscott SM, Lybarger L, Song YJ, Yang L, et al. Licensing of natural killer cells by host major histocompatibility complex class I molecules. Nature (2005) 436(7051):709-13. doi:10.1038/nature03847

37. Anfossi N, Andre P, Guia S, Falk CS, Roetynck S, Stewart CA, et al. Human NK cell education by inhibitory receptors for MHC class I. Immunity (2006) 25(2):331-42. doi:10.1016/j.immuni.2006.06.013

38. Brodin P, Lakshmikanth T, Johansson S, Karre K, Hoglund P. The strength of inhibitory input during education quantitatively tunes the functional responsiveness of individual natural killer cells. Blood (2009) 113(11):2434-41. doi:10.1182/blood-2008-05-156836 
39. Fauriat C, Ivarsson MA, Ljunggren HG, Malmberg KJ, Michaelsson J. Education of human natural killer cells by activating killer cell immunoglobulin-like receptors. Blood (2010) 115(6):1166-74. doi:10.1182/blood-2009-09245746

40. Johansson S, Johansson M, Rosmaraki E, Vahlne G, Mehr R, Salmon-Divon $\mathrm{M}$, et al. Natural killer cell education in mice with single or multiple major histocompatibility complex class I molecules. J Exp Med (2005) 201(7):1145-55. doi:10.1084/jem.20050167

41. Boulet S, Song R, Kamya P, Bruneau J, Shoukry NH, Tsoukas CM, et al. HIV protective KIR3DL1 and HLA-B genotypes influence NK cell function following stimulation with HLA-devoid cells. J Immunol (2010) 184(4):2057-64. doi:10.4049/jimmunol.0902621

42. Kamya P, Tsoukas CM, Boulet S, Routy JP, Thomas R, Cote P, et al. T cell activation does not drive $\mathrm{CD} 4$ decline in longitudinally followed HIV-infected elite controllers. AIDS Res Ther (2011) 8(1):20. doi:10.1186/1742-6405-8-20

43. Kim S, Sunwoo JB, Yang L, Choi T, Song YJ, French AR, et al. HLA alleles determine differences in human natural killer cell responsiveness and potency. Proc Natl Acad Sci U S A (2008) 105(8):3053-8. doi:10.1073/pnas.0712229105

44. Boudreau JE, Mulrooney TJ, Le Luduec JB, Barker E, Hsu KC. KIR3DL1 and HLA-B density and binding calibrate NK education and response to HIV. J Immunol (2016) 196(8):3398-410. doi:10.4049/jimmunol.1502469

45. Fernandez NC, Treiner E, Vance RE, Jamieson AM, Lemieux S, Raulet DH. A subset of natural killer cells achieves self-tolerance without expressing inhibitory receptors specific for self-MHC molecules. Blood (2005) 105(11):4416-23. doi:10.1182/blood-2004-08-3156

46. Brooks AG, Posch PE, Scorzelli CJ, Borrego F, Coligan JE. NKG2A complexed with CD94 defines a novel inhibitory natural killer cell receptor. J Exp Med (1997) 185(4):795-800. doi:10.1084/jem.185.4.795

47. Lazetic S, Chang C, Houchins JP, Lanier LL, Phillips JH. Human natural killer cell receptors involved in MHC class I recognition are disulfide-linked heterodimers of CD94 and NKG2 subunits. J Immunol (1996) 157(11):4741-5.

48. Braud VM, Allan DS, O'Callaghan CA, Soderstrom K, D'Andrea A, Ogg GS, et al. HLA-E binds to natural killer cell receptors CD94/NKG2A, B and C. Nature (1998) 391(6669):795-9. doi:10.1038/35869

49. Braud V, Jones EY, McMichael A. The human major histocompatibility complex class Ib molecule HLA-E binds signal sequence-derived peptides with primary anchor residues at positions 2 and 9. Eur J Immunol (1997) 27(5):1164-9. doi:10.1002/eji.1830270517

50. Yawata M, Yawata N, Draghi M, Partheniou F, Little AM, Parham P. MHC class I-specific inhibitory receptors and their ligands structure diverse human NK-cell repertoires toward a balance of missing self-response. Blood (2008) 112(6):2369-80. doi:10.1182/blood-2008-03-143727

51. Saunders PM, Vivian JP, O'Connor GM, Sullivan LC, Pymm P, Rossjohn J, et al. A bird's eye view of NK cell receptor interactions with their MHC class I ligands. Immunol Rev (2015) 267(1):148-66. doi:10.1111/imr.12319

52. Cella M, Longo A, Ferrara GB, Strominger JL, Colonna M. NK3-specific natural killer cells are selectively inhibited by Bw4-positive HLA alleles with isoleucine 80. J Exp Med (1994) 180(4):1235-42. doi:10.1084/jem.180.4.1235

53. Gumperz JE, Litwin V, Phillips JH, Lanier LL, Parham P. The Bw4 public epitope of HLA-B molecules confers reactivity with natural killer cell clones that express NKB1, a putative HLA receptor. J Exp Med (1995) 181(3):1133-44. doi:10.1084/jem.181.3.1133

54. Stern M, Ruggeri L, Capanni M, Mancusi A, Velardi A. Human leukocyte antigens A23, A24, and A32 but not A25 are ligands for KIR3DL1. Blood (2008) 112(3):708-10. doi:10.1182/blood-2008-02-137521

55. Wan AM, Ennis P, Parham P, Holmes N. The primary structure of HLA-A32 suggests a region involved in formation of the Bw4/Bw6 epitopes. J Immunol (1986) 137(11):3671-4.

56. Colonna M, Borsellino G, Falco M, Ferrara GB, Strominger JL. HLA-C is the inhibitory ligand that determines dominant resistance to lysis by NK1- and NK2-specific natural killer cells. Proc Natl Acad Sci U S A (1993) 90(24):12000-4. doi:10.1073/pnas.90.24.12000

57. Moesta AK, Norman PJ, Yawata M, Yawata N, Gleimer M, Parham P. Synergistic polymorphism at two positions distal to the ligand-binding site makes KIR2DL2 a stronger receptor for HLA-C than KIR2DL3. J Immunol (2008) 180(6):3969-79. doi:10.4049/jimmunol.180.6.3969

58. Winter CC, Gumperz JE, Parham P, Long EO, Wagtmann N. Direct binding and functional transfer of NK cell inhibitory receptors reveal novel patterns of HLA-C allotype recognition. J Immunol (1998) 161(2):571-7.
59. Moesta AK, Parham P. Diverse functionality among human NK cell receptors for the C1 epitope of HLA-C: KIR2DS2, KIR2DL2, and KIR2DL3. Front Immunol (2012) 3:336. doi:10.3389/fimmu.2012.00336

60. Hilton HG, Vago L, Older Aguilar AM, Moesta AK, Graef T, Abi-Rached L, et al. Mutation at positively selected positions in the binding site for HLA-C shows that KIR2DL1 is a more refined but less adaptable NK cell receptor than KIR2DL3. J Immunol (2012) 189(3):1418-30. doi:10.4049/jimmunol.1100431

61. Fellay J, Shianna KV, Ge D, Colombo S, Ledergerber B, Weale M, et al. A whole-genome association study of major determinants for host control of HIV-1. Science (2007) 317(5840):944-7. doi:10.1126/science.1143767

62. Pereyra F, Jia X, McLaren PJ, Telenti A, de Bakker PI, Walker BD, et al. The major genetic determinants of HIV-1 control affect HLA class I peptide presentation. Science (2010) 330(6010):1551-7. doi:10.1126/science.1195271

63. Davis MM, Boniface JJ, Reich Z, Lyons D, Hampl J, Arden B, et al. Ligand recognition by alpha beta T cell receptors. Annu Rev Immunol (1998) 16:523-44. doi:10.1146/annurev.immunol.16.1.523

64. Walker CM, Moody DJ, Stites DP, Levy JA. CD8+ lymphocytes can control HIV infection in vitro by suppressing virus replication. Science (1986) 234(4783):1563-6. doi:10.1126/science.2431484

65. Koup RA, Safrit JT, Cao Y, Andrews CA, McLeod G, Borkowsky W, et al. Temporal association of cellular immune responses with the initial control of viremia in primary human immunodeficiency virus type 1 syndrome. J Virol (1994) 68(7):4650-5.

66. McMichael AJ, Rowland-Jones SL. Cellular immune responses to HIV. Nature (2001) 410(6831):980-7. doi:10.1038/35073658

67. Martin MP, Qi Y, Gao X, Yamada E, Martin JN, Pereyra F, et al. Innate partnership of HLA-B and KIR3DL1 subtypes against HIV-1. Nat Genet (2007) 39(6):733-40. doi:10.1038/ng2035

68. Boulet S, Kleyman M, Kim JY, Kamya P, Sharafi S, Simic N, et al. A combined genotype of KIR3DL1 high expressing alleles and HLA-B ${ }^{\star} 57$ is associated with a reduced risk of HIV infection. AIDS (2008) 22(12):1487-91. doi:10.1097/ QAD.0b013e3282ffde7e

69. Yawata M, Yawata N, Draghi M, Little AM, Partheniou F, Parham P. Roles for HLA and KIR polymorphisms in natural killer cell repertoire selection and modulation of effector function. JExp Med (2006) 203(3):633-45. doi:10.1084/jem.20051884

70. Kamya P, Boulet S, Tsoukas CM, Routy JP, Thomas R, Cote P, et al. Receptorligand requirements for increased NK cell poly-functional potential in ${ }^{\star} \mathrm{h} /{ }^{*} \mathrm{y}+\mathrm{B} 57$ HIV-1 infected slow progressors. J Virol (2011) 85(12):5949-60. doi:10.1128/JVI.02652-10

71. Song R, Lisovsky I, Lebouche B, Routy JP, Bruneau J, Bernard NF. HIV protective KIR3DL1/S1-HLA-B genotypes influence NK cell-mediated inhibition of HIV replication in autologous CD4 targets. PLoS Pathog (2014) 10(1):e1003867. doi:10.1371/journal.ppat.1003867

72. Apps R, Qi Y, Carlson JM, Chen H, Gao X, Thomas R, et al. Influence of HLA-C expression level on HIV control. Science (2013) 340(6128):87-91. doi:10.1126/science. 1232685

73. Horowitz A, Djaoud Z, Nemat-Gorgani N, Blokhuis J, Hilton HG, Beziat V, et al. Class I HLA haplotypes form two schools that educate NK cells in different ways. Sci Immunol (2016) 1(3):1-14. doi:10.1126/sciimmunol.aag1672

74. Merino AM, Sabbaj S, Easlick J, Goepfert P, Kaslow RA, Tang J. Dimorphic HLA-B signal peptides differentially influence HLA-E- and natural killer cell-mediated cytolysis of HIV-1-infected target cells. Clin Exp Immunol (2013) 174(3):414-23. doi:10.1111/cei.12187

75. Merino AM, Song W, He D, Mulenga J, Allen S, Hunter E, et al. HLA-B signal peptide polymorphism influences the rate of HIV-1 acquisition but not viral load. J Infect Dis (2012) 205(12):1797-805. doi:10.1093/infdis/jis275

76. Gooneratne SL, Richard J, Lee WS, Finzi A, Kent SJ, Parsons MS. Slaying the Trojan horse: natural killer cells exhibit robust anti-HIV-1 antibody-dependent activation and cytolysis against allogeneic T cells. J Virol (2015) 89(1):97-109. doi:10.1128/JVI.02461-14

77. Howell DN, Andreotti PE, Dawson JR, Cresswell P. Natural killing target antigens as inducers of interferon: studies with an immunoselected, natural killing-resistant human T lymphoblastoid cell line. J Immunol (1985) 134(2):971-6

78. Lyerly HK, Reed DL, Matthews TJ, Langlois AJ, Ahearne PA, Petteway SR Jr, et al. Anti-GP 120 antibodies from HIV seropositive individuals mediate broadly reactive anti-HIV ADCC. AIDS Res Hum Retroviruses (1987) 3(4):409-22. doi:10.1089/aid.1987.3.409 
79. Trkola A, Matthews J, Gordon C, Ketas T, Moore JP. A cell line-based neutralization assay for primary human immunodeficiency virus type 1 isolates that use either the CCR5 or the CXCR4 coreceptor. J Virol (1999) 73(11):8966-74.

80. Lisovsky I, Isitman G, Bruneau J, Bernard NF. Functional analysis of NK cell subsets activated by 721.221 and K562 HLA-null cells. J Leukoc Biol (2015) 97(4):761-7. doi:10.1189/jlb.4AB1014-499R

81. Gooneratne SL, Center RJ, Kent SJ, Parsons MS. Functional advantage of educated KIR2DL1(+) natural killer cells for anti-HIV-1 antibody-dependent activation. Clin Exp Immunol (2016) 184(1):101-9. doi:10.1111/cei.12752

82. Oliva A, Kinter AL, Vaccarezza M, Rubbert A, Catanzaro A, Moir S, et al. Natural killer cells from human immunodeficiency virus (HIV)-infected individuals are an important source of CC-chemokines and suppress HIV-1 entry and replication in vitro. J Clin Invest (1998) 102(1):223-31. doi:10.1172/ JCI2323

83. Packard BZ, Telford WG, Komoriya A, Henkart PA. Granzyme B activity in target cells detects attack by cytotoxic lymphocytes. J Immunol (2007) 179(6):3812-20. doi:10.4049/jimmunol.179.6.3812

84. Mabuka J, Nduati R, Odem-Davis K, Peterson D, Overbaugh J. HIV-specific antibodies capable of ADCC are common in breastmilk and are associated with reduced risk of transmission in women with high viral loads. PLoS Pathog (2012) 8(6):e1002739. doi:10.1371/journal.ppat.1002739

85. Parsons MS, Wren L, Isitman G, Navis M, Stratov I, Bernard NF, et al. HIV infection abrogates the functional advantage of natural killer cells educated through KIR3DL1/HLA-Bw4 interactions to mediate anti-HIV antibodydependent cellular cytotoxicity. J Virol (2012) 86(8):4488-95. doi:10.1128/ JVI.06112-11

86. Lang P, Pfeiffer M, Handgretinger R, Schumm M, Demirdelen B, Stanojevic S, et al. Clinical scale isolation of T cell-depleted CD56+ donor lymphocytes in children. Bone Marrow Transplant (2002) 29(6):497-502. doi:10.1038/ sj.bmt.1703406

87. Ward JP, Bonaparte MI, Barker E. HLA-C and HLA-E reduce antibodydependent natural killer cell-mediated cytotoxicity of HIV-infected primary T cell blasts. AIDS (2004) 18(13):1769-79. doi:10.1097/00002030200409030-00005

88. Tarek N, Le Luduec JB, Gallagher MM, Zheng J, Venstrom JM, Chamberlain E, et al. Unlicensed NK cells target neuroblastoma following anti-GD2 antibody treatment. J Clin Invest (2012) 122(9):3260-70. doi:10.1172/JCI62749

89. Lisovsky I, Isitman G, Song R, DaFonseca S, Tremblay-McLean A, Lebouche B, et al. A higher frequency of NKG2A + than of NKG2A- NK cells respond to autologous HIV-infected CD4 cells irrespective of whether they co-express KIR3DL1. J Virol (2015) 89(19):9909-19. doi:10.1128/JVI.01546-15

90. Lisovsky I, Isitman G, Tremblay-McLean A, Song R, DaFonseca S, Lebouche B, et al. The differential impact of natural killer (NK) cell education via KIR2DL3 and KIR3DL1 on CCL4 secretion in the context of in-vitro HIV infection. Clin Exp Immunol (2016) 186(3):336-46. doi:10.1111/cei.12849

91. Ljunggren HG, Karre K. In search of the 'missing self': MHC molecules and NK cell recognition. Immunol Today (1990) 11(7):237-44. doi:10.1016/ 0167-5699(90)90097-S

92. Ahlenstiel G, Martin MP, Gao X, Carrington M, Rehermann B. Distinct KIR/HLA compound genotypes affect the kinetics of human antiviral natural killer cell responses. J Clin Invest (2008) 118(3):1017-26. doi:10.1172/ JCI32400

93. Trundley A, Frebel H, Jones D, Chang C, Trowsdale J. Allelic expression patterns of KIR3DS1 and 3DL1 using the Z27 and DX9 antibodies. Eur J Immunol (2007) 37(3):780-7. doi:10.1002/eji.200636773

94. Gardiner CM, Guethlein LA, Shilling HG, Pando M, Carr WH, Rajalingam R, et al. Different NK cell surface phenotypes defined by the DX9 antibody are due to KIR3DL1 gene polymorphism. J Immunol (2001) 166(5):2992-3001. doi:10.4049/jimmunol.166.5.2992

95. Boudreau JE, Le Luduec JB, Hsu KC. Development of a novel multiplex PCR assay to detect functional subtypes of KIR3DL1 alleles. PLoS One (2014) 9(6):e99543. doi:10.1371/journal.pone.0099543

96. Hilton HG, Moesta AK, Guethlein LA, Blokhuis J, Parham P, Norman PJ. The production of KIR-Fc fusion proteins and their use in a multiplex HLA class I binding assay. J Immunol Methods (2015) 425:79-87. doi:10.1016/j. jim.2015.06.012

97. Ramsuran V, Kulkarni S, O'Huigin C, Yuki Y, Augusto DG, Gao X, et al. Epigenetic regulation of differential HLA-A allelic expression levels. Hum Mol Genet (2015) 24(15):4268-75. doi:10.1093/hmg/ddv158
98. Carr WH, Pando MJ, Parham P. KIR3DL1 polymorphisms that affect NK cell inhibition by HLA-Bw4 ligand. J Immunol (2005) 175(8):5222-9. doi:10.4049/ jimmunol.175.8.5222

99. O'Connor GM, Guinan KJ, Cunningham RT, Middleton D, Parham P, Gardiner CM. Functional polymorphism of the KIR3DL1/S1 receptor on human NK cells. JImmunol (2007) 178(1):235-41. doi:10.4049/ jimmunol.178.1.235

100. Kulkarni A, Kurle S, Shete A, Ghate M, Godbole S, Madhavi V, et al. Indian long-term non-progressors show broad ADCC responses with preferential recognition of V3 region of envelope and a region from Tat protein. Front Immunol (2017) 8:5. doi:10.3389/fimmu.2017.00005

101. Baum LL, Cassutt KJ, Knigge K, Khattri R, Margolick J, Rinaldo C, et al. HIV-1 gp120-specific antibody-dependent cell-mediated cytotoxicity correlates with rate of disease progression. J Immunol (1996) 157(5):2168-73.

102. Ahmad A, Morisset R, Thomas R, Menezes J. Evidence for a defect of antibody-dependent cellular cytotoxic (ADCC) effector function and antiHIV gp120/41-specific ADCC-mediating antibody titres in HIV-infected individuals. J Acquir Immune Defic Syndr (1994) 7(5):428-37.

103. Tyler DS, Stanley SD, Nastala CA, Austin AA, Bartlett JA, Stine KC, et al. Alterations in antibody-dependent cellular cytotoxicity during the course of HIV-1 infection. Humoral and cellular defects. JImmunol (1990) 144(9):3375-84.

104. Kramski M, Parsons MS, Stratov I, Kent SJ. HIV-specific antibody immunity mediated through NK cells and monocytes. Curr HIV Res (2013) 11(5):388-406. doi:10.2174/1570162X113116660061

105. Bruel T, Guivel-Benhassine F, Amraoui S, Malbec M, Richard L, Bourdic K, et al. Elimination of HIV-1-infected cells by broadly neutralizing antibodies. Nat Commun (2016) 7:10844. doi:10.1038/ncomms10844

106. Bruel T, Guivel-Benhassine F, Lorin V, Lortat-Jacob H, Baleux F, Bourdic K, et al. Lack of ADCC breadth of human nonneutralizing anti-HIV-1 antibodies. J Virol (2017) 91(8):e2440-16. doi:10.1128/JVI.02440-16

107. Pollara J, Hart L, Brewer F, Pickeral J, Packard BZ, Hoxie JA, et al. Highthroughput quantitative analysis of HIV-1 and SIV-specific ADCC-mediating antibody responses. Cytometry A (2011) 79(8):603-12. doi:10.1002/ cyto.a. 21084

108. Smalls-Mantey A, Doria-Rose N, Klein R, Patamawenu A, Migueles SA, Ko SY, et al. Antibody-dependent cellular cytotoxicity against primary HIVinfected CD4+ T cells is directly associated with the magnitude of surface IgG binding. J Virol (2012) 86(16):8672-80. doi:10.1128/JVI.00287-12

109. Alpert MD, Harvey JD, Lauer WA, Reeves RK, Piatak M Jr, Carville A, et al. ADCC develops over time during persistent infection with live-attenuated SIV and is associated with complete protection against SIV(mac)251 challenge. PLoS Pathog (2012) 8(8):e1002890. doi:10.1371/journal.ppat. 1002890

110. Pham TN, Lukhele S, Hajjar F, Routy JP, Cohen EA. HIV Nef and Vpu protect HIV-infected CD4+ T cells from antibody-mediated cell lysis through down-modulation of CD4 and BST2. Retrovirology (2014) 11:15. doi:10.1186/1742-4690-11-15

111. Veillette M, Desormeaux A, Medjahed H, Gharsallah NE, Coutu M, Baalwa J, et al. Interaction with cellular CD4 exposes HIV-1 envelope epitopes targeted by antibody-dependent cell-mediated cytotoxicity. J Virol (2014) 88(5):2633-44. doi:10.1128/JVI.03230-13

112. Richard J, Veillette M, Batraville LA, Coutu M, Chapleau JP, Bonsignori M, et al. Flow cytometry-based assay to study HIV-1 gp120 specific antibodydependent cellular cytotoxicity responses. J Virol Methods (2014) 208:107-14 doi:10.1016/j.jviromet.2014.08.003

113. von Bredow B, Arias JF, Heyer LN, Moldt B, Le K, Robinson JE, et al. Comparison of antibody-dependent cell-mediated cytotoxicity and virus neutralization by HIV-1 Env-specific monoclonal antibodies. J Virol (2016) 90(13):6127-39. doi:10.1128/JVI.00347-16

114. Korzeniewski C, Callewaert DM. An enzyme-release assay for natural cytotoxicity. J Immunol Methods (1983) 64(3):313-20. doi:10.1016/00221759(83)90438-6

115. Kramski M, Schorcht A, Johnston AP, Lichtfuss GF, Jegaskanda S, De Rose R, et al. Role of monocytes in mediating HIV-specific antibody-dependent cellular cytotoxicity. J Immunol Methods (2012) 384(1-2):51-61. doi:10.1016/j. jim.2012.07.006

116. Gomez-Roman VR, Florese RH, Patterson LJ, Peng B, Venzon D, Aldrich K, et al. A simplified method for the rapid fluorometric assessment of 
antibody-dependent cell-mediated cytotoxicity. J Immunol Methods (2006) 308(1-2):53-67. doi:10.1016/j.jim.2005.09.018

117. Pham TN, Lukhele S, Dallaire F, Perron G, Cohen EA. Enhancing virion tethering by BST2 sensitizes productively and latently HIV-infected T cells to ADCC mediated by broadly neutralizing antibodies. Sci Rep (2016) 6:37225. doi: $10.1038 /$ srep 37225

118. Moldt B, Schultz N, Dunlop DC, Alpert MD, Harvey JD, Evans DT, et al. A panel of IgG1 b12 variants with selectively diminished or enhanced affinity for Fcgamma receptors to define the role of effector functions in protection against HIV. J Virol (2011) 85(20):10572-81. doi:10.1128/JVI.05541-11

119. Ferrari G, Pollara J, Kozink D, Harms T, Drinker M, Freel S, et al. An HIV-1 gp120 envelope human monoclonal antibody that recognizes a C1 conformational epitope mediates potent antibody-dependent cellular cytotoxicity (ADCC) activity and defines a common ADCC epitope in human HIV-1 serum. J Virol (2011) 85(14):7029-36. doi:10.1128/JVI.00171-11

120. Veillette M, Coutu M, Richard J, Batraville LA, Dagher O, Bernard N, et al. The HIV-1 gp120 CD4-bound conformation is preferentially targeted by antibody-dependent cellular cytotoxicity-mediating antibodies in sera from HIV-1-infected individuals. J Virol (2015) 89(1):545-51. doi:10.1128/ JVI.02868-14

121. Guan Y, Pazgier M, Sajadi MM, Kamin-Lewis R, Al-Darmarki S, Flinko R, et al. Diverse specificity and effector function among human antibodies to HIV-1 envelope glycoprotein epitopes exposed by CD4 binding. Proc Natl Acad Sci U S A (2013) 110(1):E69-78. doi:10.1073/pnas. 1217609110

122. Santra S, Tomaras GD, Warrier R, Nicely NI, Liao HX, Pollara J, et al. Human non-neutralizing HIV-1 envelope monoclonal antibodies limit the number of founder viruses during SHIV mucosal infection in rhesus macaques. PLoS Pathog (2015) 11(8):e1005042. doi:10.1371/journal.ppat.1005042

123. Pollara J, Bonsignori M, Moody MA, Pazgier M, Haynes BF, Ferrari G. Epitope specificity of human immunodeficiency virus-1 antibody dependent cellular cytotoxicity [ADCC] responses. Curr HIV Res (2013) 11(5):378-87. doi:10.2174/1570162X113116660059

124. Lewis GK, Finzi A, DeVico AL, Pazgier M. Conformational masking and receptor-dependent unmasking of highly conserved Env epitopes recognized by non-neutralizing antibodies that mediate potent ADCC against HIV-1. Viruses (2015) 7(9):5115-32. doi:10.3390/v7092856

125. Wyatt R, Moore J, Accola M, Desjardin E, Robinson J, Sodroski J. Involvement of the V1/V2 variable loop structure in the exposure of human immunodeficiency virus type 1 gp120 epitopes induced by receptor binding. J Virol (1995) 69(9):5723-33

126. Scheid JF, Mouquet H, Feldhahn N, Seaman MS, Velinzon K, Pietzsch J, et al. Broad diversity of neutralizing antibodies isolated from memory B cells in HIV-infected individuals. Nature (2009) 458(7238):636-40. doi:10.1038/ nature 07930

127. Mouquet H, Scharf L, Euler Z, Liu Y, Eden C, Scheid JF, et al. Complextype N-glycan recognition by potent broadly neutralizing HIV antibodies. Proc Natl Acad Sci U S A (2012) 109(47):E3268-77. doi:10.1073/pnas. 1217207109

128. Mouquet H, Klein F, Scheid JF, Warncke M, Pietzsch J, Oliveira TY, et al. Memory B cell antibodies to HIV-1 gp140 cloned from individuals infected with clade A and B viruses. PLoS One (2011) 6(9):e24078. doi:10.1371/ journal.pone. 0024078

129. Scheid JF, Mouquet H, Ueberheide B, Diskin R, Klein F, Oliveira TY, et al. Sequence and structural convergence of broad and potent HIV antibodies that mimic CD4 binding. Science (2011) 333(6049):1633-7. doi:10.1126/ science. 1207227

130. Yasmeen A, Ringe R, Derking R, Cupo A, Julien JP, Burton DR, et al. Differential binding of neutralizing and non-neutralizing antibodies to native-like soluble HIV-1 Env trimers, uncleaved Env proteins, and monomeric subunits. Retrovirology (2014) 11:41. doi:10.1186/17424690-11-41

131. Arias JF, Heyer LN, von Bredow B, Weisgrau KL, Moldt B, Burton DR, et al. Tetherin antagonism by Vpu protects HIV-infected cells from antibody-dependent cell-mediated cytotoxicity. Proc Natl Acad Sci U S A (2014) 111(17):6425-30. doi:10.1073/pnas.1321507111

132. von Bredow B, Arias JF, Heyer LN, Gardner MR, Farzan M, Rakasz EG, et al. Envelope glycoprotein internalization protects human and simian immunodeficiency virus-infected cells from antibody-dependent cell-mediated cytotoxicity. J Virol (2015) 89(20):10648-55. doi:10.1128/ JVI.01911-15

133. LuCL,MurakowskiDK, BournazosS,Schoofs T,SarkarD, Halper-StrombergA, et al. Enhanced clearance of HIV-1-infected cells by broadly neutralizing antibodies against HIV-1 in vivo. Science (2016) 352(6288):1001-4. doi:10.1126/science.aaf1279

134. Guttman M, Cupo A, Julien JP, Sanders RW, Wilson IA, Moore JP, et al. Antibody potency relates to the ability to recognize the closed, prefusion form of HIV Env. Nat Commun (2015) 6:6144. doi:10.1038/ ncomms7144

135. Richard J, Veillette M, Ding S, Zoubchenok D, Alsahafi N, Coutu M, et al. Small CD4 mimetics prevent HIV-1 uninfected bystander CD4+ T cell killing mediated by antibody-dependent cell-mediated cytotoxicity. EBioMedicine (2016) 3:122-34. doi:10.1016/j.ebiom.2015.12.004

136. Gohain N, Tolbert WD, Orlandi C, Richard J, Ding S, Chen X, et al. Molecular basis for epitope recognition by non-neutralizing anti-gp41 antibody F240. Sci Rep (2016) 6:36685. doi:10.1038/srep36685

137. Richard J, Veillette M, Brassard N, Iyer SS, Roger M, Martin L, et al. CD4 mimetics sensitize HIV-1-infected cells to ADCC. Proc Natl Acad Sci U S A (2015) 112(20):E2687-94. doi:10.1073/pnas.1506755112

138. Richard J, Pacheco B, Gohain N, Veillette M, Ding S, Alsahafi N, et al. Co-receptor binding site antibodies enable CD4-mimetics to expose conserved anti-cluster A ADCC epitopes on HIV-1 envelope glycoproteins. EBioMedicine (2016) 12:208-18. doi:10.1016/j.ebiom.2016.09.004

139. Isitman G, Lisovsky I, Tremblay-McLean A, Parsons MS, Shoukry NH, Wainberg MA, et al. Natural killer cell education does not affect the magnitude of granzyme B delivery to target cells by antibody-dependent cellular cytotoxicity. AIDS (2015) 29(12):1433-43. doi:10.1097/QAD.00000000 00000729

140. Chen Z, Freedman MS. CD16+ gammadelta T cells mediate antibody dependent cellular cytotoxicity: potential mechanism in the pathogenesis of multiple sclerosis. Clin Immunol (2008) 128(2):219-27. doi:10.1016/j. clim.2008.03.513

141. Braakman E, van de Winkel JG, van Krimpen BA, Jansze M, Bolhuis RL. CD16 on human gamma delta $\mathrm{T}$ lymphocytes: expression, function, and specificity for mouse IgG isotypes. Cell Immunol (1992) 143(1):97-107. doi:10.1016/0008-8749(92)90008-D

142. Yeap WH, Wong KL, Shimasaki N, Teo EC, Quek JK, Yong HX, et al. CD16 is indispensable for antibody-dependent cellular cytotoxicity by human monocytes. Sci Rep (2016) 6:34310. doi:10.1038/srep34310

143. Shaw GM, Levy PC, LoBuglio AF. Human monocyte antibody-dependent cell-mediated cytotoxicity to tumor cells. J Clin Invest (1978) 62(6):1172-80. doi:10.1172/JCI109236

144. Lanier LL, Ruitenberg JJ, Phillips JH. Functional and biochemical analysis of CD16 antigen on natural killer cells and granulocytes. J Immunol (1988) 141(10):3478-85.

145. Mandelboim O, Malik P, Davis DM, Jo CH, Boyson JE, Strominger JL. Human $\mathrm{CD} 16$ as a lysis receptor mediating direct natural killer cell cytotoxicity. Proc Natl Acad Sci U S A (1999) 96(10):5640-4. doi:10.1073/pnas.96.10.5640

146. Bonsignori M, Pollara J, Moody MA, Alpert MD, Chen X, Hwang KK, et al. Antibody-dependent cellular cytotoxicity-mediating antibodies from an HIV-1 vaccine efficacy trial target multiple epitopes and preferentially use the VH1 gene family. JVirol (2012) 86:11521-32. doi:10.1128/JVI. 01023-12

147. Isitman G, Tremblay-McLean A, Lisovsky I, Bruneau J, Lebouche B, Routy JP, et al. NK cells expressing the inhibitory killer immunoglobulin-like receptors (iKIR) KIR2DL1, KIR2DL3 and KIR3DL1 are less likely to be CD16+ than their iKIR negative counterparts. PLoS One (2016) 11(10):e0164517. doi:10.1371/journal.pone.0164517

148. O'Connor GM, Vivian JP, Widjaja JM, Bridgeman JS, Gostick E, Lafont BA, et al. Mutational and structural analysis of KIR3DL1 reveals a lineagedefining allotypic dimorphism that impacts both HLA and peptide sensitivity. J Immunol (2014) 192(6):2875-84. doi:10.4049/jimmunol. 1303142

149. Chung AW, Navis M, Isitman G, Wren L, Silvers J, Amin J, et al. Activation of NK cells by ADCC antibodies and HIV disease progression. J Acquir Immune Defic Syndr (2011) 58(2):127-31. doi:10.1097/QAI.0b013e31822c62b9

150. Hidajat R, Xiao P, Zhou Q, Venzon D, Summers LE, Kalyanaraman VS, et al. Correlation of vaccine-elicited systemic and mucosal nonneutralizing 
antibody activities with reduced acute viremia following intrarectal simian immunodeficiency virus SIVmac251 challenge of rhesus macaques. J Virol (2009) 83(2):791-801. doi:10.1128/JVI.01672-08

151. Burton DR, Hessell AJ, Keele BF, Klasse PJ, Ketas TA, Moldt B, et al. Limited or no protection by weakly or nonneutralizing antibodies against vaginal SHIV challenge of macaques compared with a strongly neutralizing antibody. Proc Natl Acad Sci U S A (2011) 108(27):11181-6. doi:10.1073/pnas.1103012108

152. Dugast AS, Chan Y, Hoffner M, Licht A, Nkolola J, Li H, et al. Lack of protection following passive transfer of polyclonal highly functional low-dose non-neutralizing antibodies. PLoS One (2014) 9(5):e97229. doi:10.1371/ journal.pone.0097229
Conflict of Interest Statement: The authors declare that the research was conducted in the absence of any commercial or financial relationships that could be construed as a potential conflict of interest.

Copyright (C) 2017 Bernard, Kiani, Tremblay-McLean, Kant, Leeks and Dupuy. This is an open-access article distributed under the terms of the Creative Commons Attribution License (CC BY). The use, distribution or reproduction in other forums is permitted, provided the original author(s) or licensor are credited and that the original publication in this journal is cited, in accordance with accepted academic practice. No use, distribution or reproduction is permitted which does not comply with these terms. 